\title{
NoTE
}

\section{Fernandez-Vargas v. Gonzales: Due Process Concerns, Probable Consequences, and Possible Solutions}

\section{INTRODUCTION}

Early one morning in November 2003, Mr. Humberto "Bert" Fernandez-Vargas said goodbye to his family and drove to the U.S. Bureau of Citizenship and Immigration Services (BCIS) ${ }^{1}$ office in Salt Lake City, Utah. ${ }^{2}$ Fernandez-Vargas appeared at the BCIS office expecting a routine interview regarding his pending application for permanent residence. ${ }^{3}$ However, instead of attending an interview that would move him one step closer to attaining lawful permanent residence inside the United States, Fernandez-Vargas was arrested for being in the country illegally and detained until his removal could be finalized. ${ }^{4}$ On

Brian D. Bumgardner. J.D. candidate 2007, University of Kansas School of Law; B.A. 1999, University of North Carolina at Chapel Hill. I would like to thank Professor Sandra Craig McKenzie, Kyle Binns, and Adam Davis for their insightful feedback during the writing of this Note. I would also like to thank my friends and family for their support during the last three years.

1. The BCIS was an agency within the U.S. Department of Homeland Security (DHS) that replaced the Immigration and Naturalization Service (INS). On November 1, 2003, the BCIS was replaced by the USCIS - the U.S. Citizenship and Immigration Services-within the DHS.

2. Dennis Romboy, Outcast in Mexico, Outlaw in Utah, DeSERET Morning News (Salt Lake City, Utah), Oct. 9, 2005, at A01.

3. See Fernandez-Vargas v. Ashcroft, 394 F.3d 881, 883 (10th Cir. 2005) ("[A]pparently at an interview regarding his application, Fernandez was arrested for being in the country illegally."), aff' $d$ sub nom Fernandez-Vargas v. Gonzales, 126 S. Ct. 2422 (2006). "Lawful permanent residence" refers to a foreign national's visa status. A person who is a permanent resident is allowed to reside indefinitely within the United States as an immigrant, despite not having U.S. citizenship. See Immigration and Nationality Act $\S 101(a)(20), 8$ U.S.C. $§ 1101(a)(20)$ (2000) (defining "lawfully admitted for permanent residence"). Lawful permanent residents are also commonly referred to as "green card holders." See Ernest R. Larkins, Coming to America: International Students Face a Labyrinth of Income Tax Issues, 15 CONN. J. INT'L L. 47, 48 (2000) ("Permanent immigrants are sometimes called green card holders since years ago the card's color was green.").

4. Fernandez-Vargas, 126 S. Ct. at 2427. Prior to 1996, "noncitizens who were found to be 'inadmissible,' and who did not receive discretionary relief, were 'excluded"' from the United States. STEPHEN H. LegOMSKY, ImMigration AND Refugee LAW AND Policy 411 (4th ed. 2005). "Those who were ... [deemed] 'deportable,' and who did not receive discretionary relief, were 'deported." Id. The enactment of the Illegal Immigration and Immigrant Responsibility Act of 1996 (IIRIRA) changed this vocabulary. After IIRIRA, "noncitizens who are found either 
September 6, 2004, after Fernandez-Vargas had been in custody for ten months, the government removed him from the United States. ${ }^{5}$ After nearly two decades of residing inside the country, ${ }^{6}$ Fernandez-Vargas ended up where he began: back in Mexico. His wife and fourteen-yearold son, both citizens of the United States, ${ }^{7}$ remained at the family's home in Utah. ${ }^{8}$

Fernandez-Vargas was arrested, detained, and summarily removed because he had reentered the United States illegally after having previously been deported in 1981. ${ }^{9}$ Specifically, Fernandez-Vargas was removed according to the authority granted to the administrative branch of government by $\S 241(\mathrm{a})(5)$ of the Immigration and Nationality Act (INA), ${ }^{10}$ commonly known as the "reinstatement provision." 11 This provision, enacted as part of the Illegal Immigration Reform and Immigrant Responsibility Act of 1996 (IIRIRA), ${ }^{12}$ allows the federal government to reinstate previous deportation or removal orders against aliens who have illegally reentered the United States. ${ }^{13}$ The provision also provides that when prior orders are reinstated, those orders are not subject to being reopened or reviewed, and the affected alien is not eligible and may not apply for any forms of discretionary relief found within the INA. ${ }^{14}$

Following his arrest, Fernandez-Vargas appealed for review of his prior deportation order's reinstatement. ${ }^{15} \mathrm{He}$ argued that because he illegally reentered the country prior to the IIRIRA's April 1, 1997 effective date, the controlling statutory section was the more forgiving, pre-IIRIRA provision. ${ }^{16}$ Unlike $\S 241(\mathrm{a})(5)$, this former provision would

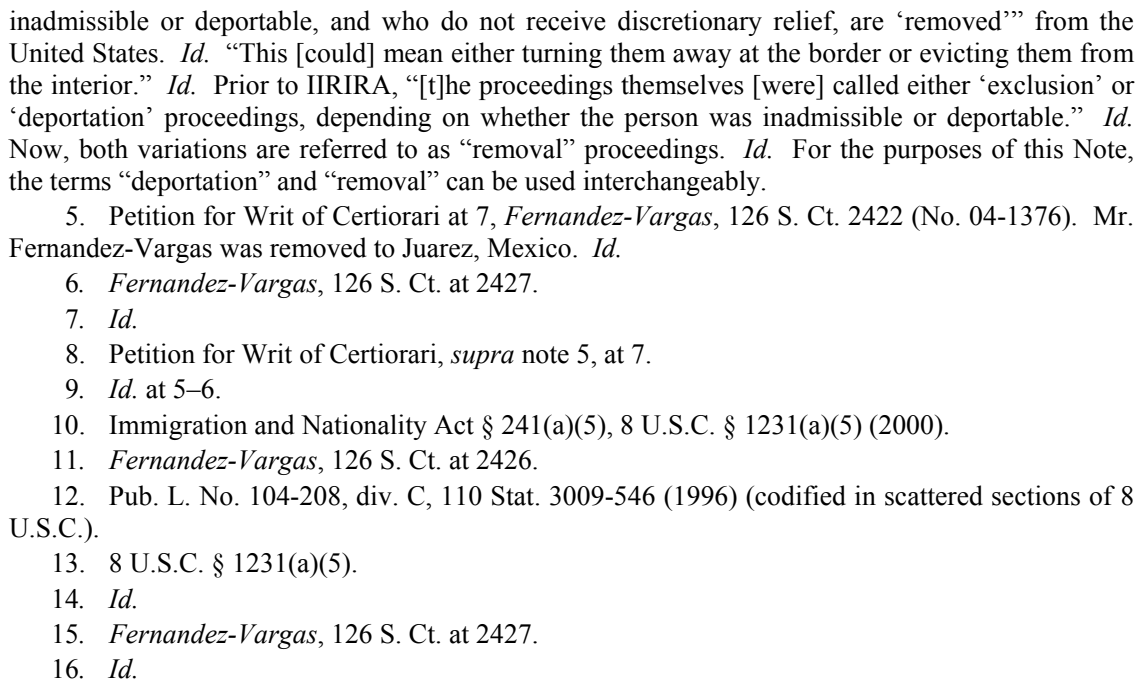


have allowed Fernandez-Vargas to apply for discretionary relief from removal. ${ }^{17}$ Because the new reinstatement provision explicitly barred all forms of relief that were available to Fernandez-Vargas at the time of his reentry, he argued that its application to his case would render an impermissible retroactive effect. ${ }^{18}$

Citing a split amongst the lower courts, the Supreme Court of the United States granted certiorari to resolve the issue of whether $\S$ 241(a)(5) controls reinstatement of a removal order when the alien illegally reentered prior to the IIRIRA's effective date. ${ }^{19}$ In June 2006, the Court held that $\S 241(\mathrm{a})(5)$ has no impermissible retroactive effect as applied to such aliens, and affirmed the removal of Fernandez-Vargas. ${ }^{20}$ Now, Fernandez-Vargas, living separated from his family in Cuauhtémoc, Mexico, ${ }^{21}$ is permanently inadmissible and ineligible to regularize his immigration status inside the country. ${ }^{22}$ He may seek a waiver of that permanent inadmissibility, but only after spending at least ten years outside of the United States. ${ }^{23}$

This Note argues that, in limited circumstances, the procedures provided for by the current reinstatement provision violate traditional notions of due process, an argument not addressed by the Supreme Court in Fernandez-Vargas. However, this Note does not contend that all applications of the reinstatement provision offend the Constitution. Rather, it argues that under facts similar to those of Fernandez-Vargaswhere a noncitizen is removed following an initial hearing on the merits, illegally reenters the country, remains undetected for an extended period of time, and subsequently develops new ties and property interests inside the United States - the Due Process Clause requires a second hearing in order to account for the alien's change in circumstances. Because Fernandez-Vargas's 1981 deportation hearing occurred more than twenty years before his removal in 2004, reinstatement of the prior deportation order without a second hearing was insufficient to protect the property and liberty interests he had acquired during his twenty-year stay inside

17. See discussion infra Part II.B (comparing the former and current reinstatement provisions of the INA).

18. Fernandez-Vargas, $126 \mathrm{~S}$. Ct. at 2427.

19. Id.

20. Id. at 2434 .

21. Dennis Romboy, Deportee Can't Come Home, DeSERET Morning News (Salt Lake City, Utah), June 23, 2006, at A01.

22. Immigration and Nationality Act $\S 212(\mathrm{a})(9)(\mathrm{C})(\mathrm{i})(\mathrm{II}), 8$ U.S.C. $\S 1182(\mathrm{a})(9)(\mathrm{C})(\mathrm{i})(\mathrm{II})$ (2000).

23. Id. $\S 212(\mathrm{a})(9)(\mathrm{B})(\mathrm{i})(\mathrm{II})$. 
the United States. Since interests in personal property, ${ }^{24}$ vehicles, ${ }^{25}$ real property, ${ }^{26}$ and the relationship between parents and their children ${ }^{27}$ are protectable property interests within the meaning of the Due Process Clause of the Fifth Amendment, the Court's holding deprived FernandezVargas of these property interests without due process of law.

Part II discusses the background of Fernandez-Vargas in greater detail. In addition, Part II outlines both the current deportation reinstatement provision, $\S 241(\mathrm{a})(5)$, as well as the former reinstatement provision in effect at the time of Fernandez-Vargas's last illegal reentry into the United States. Finally, Part II addresses Congress's plenary power to regulate immigration matters and the requirements of the Due Process Clause. Part III argues that the new reinstatement provision offends traditional notions of due process when applied to long-term, illegal reentrants, such as Fernandez-Vargas, by depriving these individuals of protectable property interests without a fair and impartial hearing. Part III also discusses how separating mixed-status familiesconsisting of both U.S. citizen and non-U.S. citizen members-is contrary to promoting family unity, and argues that courts could avoid this harsh result in cases similar to Fernandez-Vargas by holding that the current reinstatement provision violates the Due Process Clause.

\section{BACKGROUND}

\section{A. Fernandez-Vargas Illegally Reentered the United States in 1981 and Remained Undetected for Two Decades}

Fernandez-Vargas, a native and citizen of Mexico, first came to the United States as a teenager around $1970{ }^{28}$ During the 1970 s and early 1980s, he was deported several times for immigration violations. ${ }^{29}$ After being deported in 1981, Fernandez-Vargas illegally reentered the country in January $1982^{30}$ and remained undetected by immigration authorities for twenty years. ${ }^{31}$ For the majority of this time, Fernandez-Vargas resided in Utah, where he worked as a truck driver and owned his own

\footnotetext{
24. Brown v. Knapp, 156 F. Supp. 2d 732, 736 (N.D. Ill. 2001).

25. Robledo v. City of Chi., 444 F. Supp. 2d 895, 900 (N.D. Ill. 2006).

26. United States v. Land, Winston County, 163 F.3d 1295, 1301 (11th Cir. 1998).

27. Quilloin v. Walcott, 434 U.S. 246, 255 (1978); State v. Robert H., 393 A.2d 1387, 1388-89

(N.H. 1978), overruled on other grounds by In re Craig T., 800 A.2d 819, 823 (N.H. 2002).

28. Romboy, supra note 21.

29. Petition for Writ of Certiorari, supra note 5, at 5 .

30. Id.

31. Id. at 5-6.
} 
trucking business. ${ }^{32}$ On March 30, 2001, he married his long-term girlfriend, Rita Fernandez, a citizen of the United States. ${ }^{33}$ Several years earlier, Rita had given birth to Fernandez-Vargas's son, Anthony, who is also a U.S. citizen. ${ }^{34}$

Following his marriage, Fernandez-Vargas took affirmative steps to legalize his immigration status inside the country. Based on a petition that Rita had filed on his behalf with the Immigration and Naturalization Service (INS), ${ }^{35}$ Fernandez-Vargas filed two applications that, if approved, would allow him to obtain the status of a lawful permanent resident inside the United States, despite his previous deportations and illegal reentries. ${ }^{36}$ As part of these filings, the couple paid a $\$ 1000$ "penalty" fee to cure Fernandez-Vargas's illegal entry into the United States. ${ }^{37}$ The INS accepted his applications and authorized his employment inside the United States. ${ }^{38}$ However, these filings apparently tipped off federal authorities as to Fernandez-Vargas's illegal reentry into the country. ${ }^{39}$ In November 2003, the government began proceedings under INA $\S 241(\mathrm{a})(5)$ that eventually led to the reinstatement of Fernandez-Vargas's 1981 deportation order and his removal from the United States. ${ }^{40}$

\section{B. The Current Reinstatement Provision Explicitly Denies Relief}

Previously Available Under the Former Provision

1. Under the Former Deportation Reinstatement Provision, Various

Forms of Discretionary Relief Were Available to Affected Aliens

Prior to the current deportation reinstatement provision's enactment in 1996, deportation reinstatement was governed by INA $\S 242(\mathrm{f}){ }^{41}$ This former provision read:

32. Id. at 6 .

33. $I d$.

34. Id.

35. Id.

36. Fernandez-Vargas v. Ashcroft, 394 F.3d 881, 883 (10th Cir. 2005), aff'd sub nom Fernandez-Vargas v. Gonzales, 126 S. Ct. 2422 (2006).

37. Petition for Writ of Certiorari, supra note 5, at 6.

38. Id.

39. Fernandez-Vargas, 126 S. Ct. at 2427.

40. Id.

41. Immigration and Nationality Act $\S 242(f), 8$ U.S.C. § 1252(f) (1994), amended by Illegal Immigration and Immigrant Responsibility Act of 1996, Pub. L. No. 104-208 § 306(a)(2), 110 Stat. 3009-607 (1996). 
Should the Attorney General find that any alien has unlawfully reentered the United States after having previously departed or been deported pursuant to an order of deportation, whether before or after June $27,1952, \ldots$ the previous order of deportation shall be deemed to be reinstated from its original date and such alien shall be deported under such previous order at any time subsequent to such reentry.

However, despite the provision's sweeping language, only a limited class of unlawful reentrants, such as those deported for aggravated felony convictions, were actually affected by the reinstatement order. ${ }^{43}$ In addition, even those unlawful reentrants who were affected by this provision could seek some forms of discretionary relief. ${ }^{44}$ For example, under former INA $\S 244(a)(1)$, suspension of deportation was available to unlawful reentrants who demonstrated continuous presence in the United States for a period of seven years, had good moral character, and convinced the reviewing body that deportation would result in "extreme hardship" to the alien or to a U.S. citizen or permanent resident who was the alien's spouse, parent, or child. ${ }^{45}$ Moreover, under pre-IIRIRA regulations, persons subject to reinstatement of a prior deportation order were entitled to a hearing before an immigration judge regarding the merits of the reinstatement. ${ }^{46}$ At this hearing, the person facing reinstatement had the right to counsel and the opportunity to develop an administrative record. ${ }^{47}$ The immigration judge's decision was subject to review. $^{48}$ Finally, a person facing the reinstatement of an earlier deportation order could request discretionary relief by seeking to adjust his or her status to that of a lawful permanent resident. ${ }^{49}$

\footnotetext{
42. Id.

43. Fernandez-Vargas v. Ashcroft, 394 F.3d 881, 887 (10th Cir. 2005), aff'd sub nom Fernandez-Vargas, 126 S. Ct. 2422.

44. Id.

45. Immigration and Nationality Act $\S 244(a), 8$ U.S.C. § 1254(a) (1995), amended by Illegal Immigration and Immigrant Responsibility Act of 1996, Pub. L. No. 104-208 § 308(b)(7), 110 Stat. 3009-615 (1996).

46. 8 C.F.R. § 242.23 (removed 1997); § 242.1(b) (removed 1997).

47. § 242.23 (removed 1997); § 242.10 (removed 1997); § 242.15 (removed 1997).

48. § 242.23 (removed 1997); § 242.21 (removed 1997).

49. Immigration and Nationality Act $\S 245(\mathrm{i}), 8$ U.S.C. 1255 (i) (2000); 8 C.F.R. $\S 242.17$ (a) (removed 1997).
} 
2. The Current Deportation Reinstatement Provision Denies Any and All Forms of Relief Available Under the INA

President Clinton signed the IIRIRA into law on September 30, 1996, and it became effective as of April 1, 1997. ${ }^{50}$ In the IIRIRA, Congress replaced the former reinstatement provision with one that toed a harder line. The current deportation reinstatement provision, codified at INA $\S 241(\mathrm{a})(5)$, reads:

If the Attorney General finds that an alien has reentered the United States illegally after having been removed or having departed voluntarily, under an order of removal, the prior order of removal is reinstated from its original date and is not subject to being reopened or reviewed, the alien is not eligible and may not apply for any relief under this chapter and the alien shall be removed under the prior order at any time after the reentry.

INA $\S 241(\mathrm{a})(5)$ differs from its predecessor, INA $\S 242(\mathrm{f})$, in a number of material respects. First, the current provision expands the category of illegal reentrants who may be subjected to reinstatement of a previous deportation order. ${ }^{52}$ Whereas the former provision only authorized reinstatement for those who had been deported for certain enumerated reasons, $\S 241(\mathrm{a})(5)$ authorizes reinstatement of prior removal orders for all illegal reentrants previously deported for any reason. ${ }^{53}$ Second, persons subject to reinstatement of a previous order are no longer entitled to a hearing before an immigration judge. ${ }^{54}$ Instead, a summary administrative procedure may be used in which an immigration official, not a judge, makes all the necessary determinations concerning the decision to redeport an individual. ${ }^{55}$ In addition, a person facing reinstatement of a prior deportation order may not avoid removal by seeking discretionary relief from the Attorney General. ${ }^{56}$ This final difference effectively eliminates the ability of a reentrant to legalize his or her status inside the United States once an individual has exited the country under an order of removal.

50. Illegal Immigration and Immigrant Responsibility Act of 1996, Pub. L. No. 104-208, div. C, 110 Stat. 3009-546 (1996) (codified in scattered sections of 8 U.S.C.).

51. Immigration and Nationality Act $\S 241(a)(5), 8$ U.S.C. $\S 1231(a)(5)$ (2000).

52. Fernandez-Vargas v. Gonzales, 126 S. Ct. 2422, 2426 (2006).

53. Id.

54. Id.

55. 8 C.F.R. $\S 241.8($ b) (2006).

56. Fernandez-Vargas, 126 S. Ct. at 2426. 


\section{The Supreme Court Found Fernandez-Vargas's Retroactivity Argument Unconvincing}

In his petition, Fernandez-Vargas argued that because his illegal reentry occurred in 1981, well before the enactment of the IIRIRA, his case should be governed by the more-forgiving dictates of pre-IIRIRA law. ${ }^{57}$ Accordingly, Fernandez-Vargas maintained his eligibility to seek discretionary relief from removal under INA $\S 242(f){ }^{58}$ FernandezVargas argued that $\S 241(a)(5)$ 's application would be impermissibly retroactive because it "would impair rights a party possessed when he acted [or] increase a party's liability for past conduct" by taking away the discretionary relief formerly available under $\S 242(\mathrm{f}) .^{59}$

In support of his argument, Fernandez-Vargas relied on three observations. First, the older reinstatement provision contained a "before-or-after" clause that expressly gave it retroactive effect, whereas Congress removed this clause from the new statute. ${ }^{60}$ He reasoned that had Congress intended for the IIRIRA's new reinstatement provision to apply to reentries that occurred prior to its enactment, Congress would have retained this express clause of retroactivity. ${ }^{61}$ Second, Congress had deliberately removed language that expressly gave the provision retroactive effect from early drafts of $\S 241(\mathrm{a})(5) .{ }^{62}$ Finally, FernandezVargas argued that because Congress is well aware of the traditional presumption against retroactivity, the legislative branches would have known to include more specific language if it wanted $\S 241(a)(5)$ to apply retroactively. ${ }^{63}$

On June 22, 2006, the Supreme Court of the United States, in an eight-to-one decision, held that $\S 241(\mathrm{a})(5)$ is not impermissibly retroactive when applied to aliens who illegally reentered the country before the IIRIRA's effective date, affirming the summary reinstatement of Fernandez-Vargas's deportation order. ${ }^{64}$ The Court found that Congress's elimination of the express "before-or-after" clause from the current provision did not clearly indicate that Congress intended the law

57. Id. at 2427.

58. Id.

59. Id. at $2427-28$.

60. Id. at 2429; Petition for Writ of Certiorari, supra note 5, at 14 (citing Castro-Cortez v. INS, 239 F.3d 1037, 1051 (9th Cir. 2001)).

61. Petition for Writ of Certiorari, supra note 5, at 14.

62. Id. at $14-15$.

63. Id. at 15 .

64. Fernandez-Vargas, $126 \mathrm{~S}$. Ct. at 2434. 
to apply only to postenactment reentrants. ${ }^{65}$ The Court noted that the point of the statute's revision was to "expand the scope of the reinstatement authority . . . and it would make no sense to infer that Congress meant to except [this] broad class of persons." "66 "[Congress was] trying to get out of the country people who were here illegally, twotime losers who were here illegally for the second time." concluded that $\S 241(\mathrm{a})(5)$ applied not because Fernandez-Vargas reentered at any particular time, but because he chose to illegally remain in the United States after the new statute became effective. ${ }^{68}$ The Court stated,

[T]he statute applies to stop an indefinitely continuing violation that the alien himself could end at any time by voluntarily leaving the country. It is therefore the alien's choice to continue his illegal presence, after illegal reentry and after the effective date of the new law, that subjects him to the new and less generous legal regime.... ${ }^{69}$

\section{The Political Branches' Plenary Power to Regulate Immigration Matters is Limited by Constitutional Restraints}

Unlike the arguments presented by Fernandez-Vargas, this Note focuses on the sufficiency of due process protections provided by the current reinstatement provision as applied to Fernandez-Vargas and a niche of similarly situated noncitizens - those who illegally reentered the country after being removed, remained undetected for an extended period of time, and, during this extended period, developed new ties and property interests that did not exist at the noncitizen's first removal hearing. As background to this argument, it should be noted that Congress generally has plenary power to regulate matters related to immigration. ${ }^{70}$ The Supreme Court has long recognized that the political branches of the federal government are responsible for regulating the relationship between the United States and foreign immigrant visitors,

65. Id. at 2429 .

66. Id.

67. Transcript of Oral Argument at 19, Fernandez-Vargas, 126 S. Ct. 2422 (No. 04-1376) (quoting Scalia, J.).

68. Fernandez-Vargas, $126 \mathrm{~S}$. Ct. at 2432.

69. Id.

70. This doctrine, known as the plenary-power doctrine, simply states that congressional authority over immigration matters is "absolute and unchecked." Sara A. Martin, Note, Postcards from the Border: A Result-Oriented Analysis of Immigration Reform under the AEDPA and IIRIRA, 19 B.C. THIRD WORLD L.J. 683, 696 (1999). 
stating that " over no conceivable subject is the legislative power of Congress more complete than it is over' the admission of aliens." ${ }^{, 71}$ As a result, both the Supreme Court and the lower courts have consistently interpreted the plenary-power doctrine to allow the application of congressional rules to noncitizens that would be unconstitutional if applied to citizens. ${ }^{72}$

However, Congress's plenary power over immigration-related matters is not without limits. In 1903, the Supreme Court, in Yamataya v. Fisher ${ }^{73}$ addressed the Legislative Branch's authority to evict noncitizens from the United States. The Court reviewed an administrative finding that a foreign immigrant was deportable on grounds that she was a pauper and "likely to become a public charge." "74 The Court held that a noncitizen who is present in the United States, even if present illegally, shall not be "taken into custody and deported without giving him all opportunity to be heard upon the questions involving his right to be and remain in the United States."75 "According to the [] Court, the plenary-power doctrine is not a doctrine of absolute power, nor is it a means of circumventing the Constitution. Rather, it is a doctrine under which the political branches exercise broad authority, subject to the provisions of the Constitution." 76

In 1952, the Court again alluded that Congress's plenary power over immigration was not absolute. In Harisiades v. Shaughnessy, ${ }^{77}$ the Court indicated that any action Congress takes in matters related to immigration is "largely immune from judicial inquiry or interference." "78 It has been noted that the Court's choice of words is significant here. In choosing to say "largely immune" rather than "immune" or "wholly immune," the Court recognized that the plenary power is not absolute. ${ }^{79}$

71. Fiallo v. Bell, 430 U.S. 787, 792 (1977) (quoting Oceanic Navigation Co. v. Stranahan, 214 U.S. 320, 339 (1909)).

72. See, e.g., Mathews v. Diaz, 426 U.S. 67, 79-80 (1976) ("In the exercise of its broad power over naturalization and immigration, Congress regularly makes rules that would be unacceptable if applied to citizens."); Fong Yue Ting v. United States, 149 U.S. 698, 732 (1893) (upholding racially based deportation law directed at Chinese laborers).

73. 189 U.S. 86 (1903).

74. Id. at 94,97 .

75. Id. at 101.

76. Trevor Morrison, Note, Removed from the Constitution? Deportable Aliens' Access to Habeas Corpus Under the New Immigration Legislation, 35 COLUM. J. TRANSNAT'L L. 697, 717 (1997).

77. 342 U.S. 580 (1952).

78. Id. at 589 (emphasis added).

79. Morrison, supra note 76, at $711 \mathrm{n} .83$. 


\section{ANALYSIS}

A. INA \& 241(a)(5) Offends Traditional Notions of Due Process Rights as Applied to Fernandez-Vargas and Similarly Situated, Long-Term Illegal Reentrants

1. Constitutional Due Process Protections Extend to All 'Persons' Within the United States

Traditionally, the Fifth Amendment to the Constitution has extended its protections to citizens of the United States. However, on its face, the Due Process Clause provides that " $[\mathrm{n}] \mathrm{o}$ person shall ... be deprived of life, liberty, or property, without due process of law." this language, the Supreme Court has held that these provisions are universal in their application to all persons within the United States, not just citizens, regardless of any differences in race, color, or nationality. ${ }^{81}$ Even noncitizens who are unlawfully present in the United States have been recognized as "persons" guaranteed due process of law by the Fifth and Fourteenth Amendments. ${ }^{82}$ In Plyler v. Doe, the Court stated that although "a person's initial entry into ... the United States, was unlawful ... [this] cannot negate the simple fact of his presence within the [country's] territorial perimeter." ${ }^{, 3}$ In 1976, the Court reaffirmed this position by again finding that noncitizens who have entered the country, either legally or illegally, are entitled to constitutional due process protections. ${ }^{84}$ The Court found that "[t]he Fifth Amendment, as well as the Fourteenth Amendment, protects every ... person[] from deprivation of life, liberty, or property without due process of law. Even one whose presence in this country is unlawful, involuntary, or transitory is entitled to that constitutional protection." 85

2. Fernandez-Vargas is a "Person" Within the Meaning of the Due Process Clause

Although the INA labels Fernandez-Vargas as an "alien" or an "illegal," it does not negate the fact that he is a human; and although he

\footnotetext{
80. U.S. CONST. amend. V (emphasis added).

81. Yick Wo v. Hopkins, 118 U.S. 356, 369 (1886).

82. Plyler v. Doe, 457 U.S. 202, 210 (1982).

83. Id. at 215 .

84. Mathews v. Diaz, 426 U.S. 67, 77 (1976).

85. Id.
} 
is not a U.S. citizen, he is a "person" within the meaning of the Fifth Amendment. Even though Fernandez-Vargas illegally reentered the United States in January of 1982, that fact does not erase his presence within the territorial limits of the country. It follows that FernandezVargas is entitled to any and all protections provided by the Fifth Amendment. These protections include the right to receive notice and the opportunity for a meaningful hearing before being deprived of life, liberty, or property. ${ }^{86}$ Although Fernandez-Vargas did presumably receive a "meaningful" hearing at the time of his first deportation, during the period he remained in the country undetected, his circumstances changed so drastically that his initial deportation hearing, occurring over twenty years earlier, no longer can be considered "meaningful."

\section{Fernandez-Vargas Developed Several Protectable Property Interests}

In order to state a claim for a violation of due process, a person must show a cognizable property or liberty interest and show a deprivation of that interest without due process. ${ }^{87}$ Cognizable property interests are not created by the Constitution. ${ }^{88}$ "Rather they are created and ... defined by existing rules or understandings that stem from an independent source such as state law-rules or understandings that secure certain benefits and that support claims of entitlement to those benefits." 89 Courts have found that persons have a protectable property interest in their vehicles and other personal property. ${ }^{90}$ In addition, the Supreme Court has found that personal residences, as well as all real property, are protectable property interests and require notice and an opportunity to be heard before a deprivation may occur. ${ }^{91}$

During the twenty-year period following Fernandez-Vargas's illegal reentry, he developed several protectable property interests within the meaning of the Due Process Clause. Fernandez-Vargas's last deportation occurred in 1981; he reentered the country the following year, and then

86. See United States v. Land, Winston County, 163 F.3d 1295, 1298 (11th Cir. 1998) (stating that individuals must receive notice and an opportunity to be heard before the government deprives them of real property).

87. Omosegbon v. Wells, 335 F.3d 668, 674 (7th Cir. 2003).

88. Bd. of Regents v. Roth, 408 U.S. 564, 577 (1972).

89. Id.

90. See, e.g., Sutton v. City of Milwaukee, 672 F.2d 644, 645 (7th Cir. 1982) (noting that a person's car is property and is therefore protectable within the meaning of the Due Process Clause); Brown v. Knapp, 156 F. Supp. 2d 732, 736 (N.D. Ill. 2001) ("The Due Process Clause of the Fourteenth Amendment prohibits the deprivation of personal property ....").

91. United States v. James Daniel Good Real Prop., 510 U.S. 43, 61 (1993). 
spent the next twenty years living and working inside the United States. During this time, he developed substantial ties to the country. In particular, Fernandez-Vargas established a business and purchased a small home in Utah. In association with his business, he owned two semitrucks, as well as other equipment. ${ }^{92}$ When Fernandez-Vargas was summarily deported, he was deprived of these personal and real property interests without the benefit of a meaningful hearing. Because his first deportation hearing occurred before Fernandez-Vargas acquired this property, it did not provide the due process protections mandated by the Fifth Amendment.

The Court has also noted that the "property interests protected by procedural due process extend well beyond actual ownership of real estate, chattels, or money." 93 In addition to these tangible forms of property, courts have recognized that individuals may possess other intangible property rights and liberty interests. For example, the Supreme Court has held that the relationship between a parent and a child is constitutionally protected. ${ }^{94}$ In reaching this conclusion, the Court reiterated that "[i]t is cardinal with us that the custody, care and nurture of the child reside first in the parents ....' And it is now firmly established that 'freedom . . . in matters of . . family life is one of the liberties protected by the Due Process Clause ...." 995 Other courts have also commented on the elevated status of parental-child relationships. In State v. Robert H. ${ }^{96}$ the Supreme Court of New Hampshire stated that "[t]he role of parents in the life of a family has attained the status of a fundamental human right and liberty."

Although the Court in Quilloin v. Walcott was addressing whether a father could block the adoption of his illegitimate child, ${ }^{98}$ the same fundamental principles articulated by the Court should apply to other parent-child relationships. Similarly, although the court in Robert $H$. dealt specifically with custody issues, ${ }^{99}$ its characterization of the nature of a parent's role in a child's life as a "fundamental human right and liberty" 100 should not be limited solely to this context. The issues raised

92. Romboy, supra note 2.

93. Roth, 408 U.S. at $571-72$.

94. Quilloin v. Walcott, 434 U.S. 246, 255 (1978).

95. Id. (quoting Cleveland Bd. of Educ. v. LaFleur, 414 U.S. 632, 639-46 (1974)).

96. 393 A.2d 1387 (N.H. 1978), overruled on other grounds by In re Craig T., 800 A.2d 819 (N.H. 2002).

97. Id. at 1388 .

98. Quilloin, 434 U.S. at 247.

99. Robert H., 393 A.2d at 1387-88.

100. Id. at 1388. 
in adoption and custody cases are closely analogous to family issues raised in some reinstatement cases - specifically, where an illegal reentrant returns to the United States, marries a U.S. citizen, and fathers or gives birth to a U.S.-citizen child. In each context, decisions are made that will affect the fundamental relationship between a parent and his or her child. In the deportation context, if the noncitizen parent is summarily removed from the United States without a meaningful hearing, that parent is also being summarily removed from the child's life without an opportunity to keep the family unit together by seeking discretionary relief. Summarily removing such illegal reentrants either deprives the noncitizen of a fundamental liberty interest without due process, or effectively deports the U.S.-citizen spouse and child if they choose to leave the United States and follow the removed noncitizen.

While no court has followed the exact logic outlined above concerning the parent-child relationships of reentrants, the Supreme Court has addressed similar issues in the context of a lawful permanent resident. In 1982, the Court recognized that "once an alien gains admission to our country and begins to develop the ties that go with permanent residence his constitutional status changes accordingly," ${ }^{101}$ as these ties entitle the alien to an increased level of due process. ${ }^{102}$ Although the subject of deportation in Landon v. Plasencia was a legal permanent resident, the logic used by the Court is applicable to Fernandez-Vargas. In Landon, the Court identified the petitioner's rights "to stay and live and work" as "weighty."103 The Court also recognized the right of a noncitizen to "rejoin her immediate family" as a protectable interest and one that "ranks high among the interests of the individual." 104 A noncitizen, whether legally or illegally present in the country, may develop similar ties over an extended period of time. Because Fernandez-Vargas was present inside the United States for twenty years, he developed strong family and community bonds which should be viewed as cognizable property and liberty interests within the scope of the Due Process Clause.

101. Landon v. Plasencia, 459 U.S. 21, 32 (1982).

102. Id.

103. Id. at 34 .

104. Id. 
4. The Current Reinstatement Procedures Failed to Provide FernandezVargas with Adequate Constitutional Protections Before Depriving Him of Protectable Property and Liberty Interests

Despite the fact that the plenary-power doctrine confers considerable discretion over immigration matters to the political branches of government, this power is not exercised without constraints. ${ }^{105}$ Instead, the Constitution limits expressions of the plenary power, and it remains the judiciary's role to enforce these limitations. ${ }^{106}$ Therefore, it is the duty of the judiciary to ensure that the political branches do not abrogate the constitutional rights vested in noncitizens. Where a statutory provision exceeds its constitutional authority, it should be declared invalid. $^{107}$

Under the current reinstatement regulations, in order to reinstate a prior order of removal, an immigration officer must determine: (1) whether the noncitizen has been subject to the prior order of removal; (2) the identity of the noncitizen; and (3) whether the noncitizen unlawfully reentered the United States (based on all relevant evidence, including any statements made by the noncitizen). ${ }^{108}$ When an immigration officer determines that a noncitizen is subject to removal under 8 C.F.R. $\S$ 241.8 , the officer must advise the noncitizen that he can make a written or oral statement contesting the determination. ${ }^{109}$ If the noncitizen makes a statement, the officer is directed to consider whether the statement warrants reconsideration of the determination. ${ }^{110}$ If the officer remains convinced that the noncitizen is subject to removal, the noncitizen shall be removed under the previous order of exclusion, deportation, or removal without further hearing. ${ }^{111}$ These reinstatement orders are issued by low-level immigration officers, not immigration judges. ${ }^{112}$ The orders are often executed within hours or days. ${ }^{13}$ Once an order is

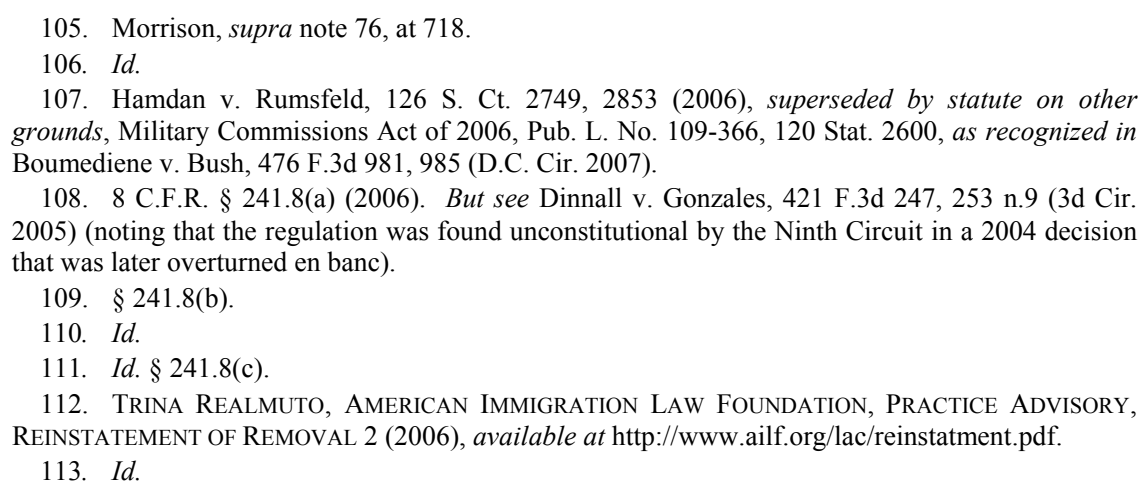


issued, it is not subject to being opened or reviewed by a judicial officer. ${ }^{114}$ Any noncitizen subject to the reinstatement provision is "not eligible and may not apply for any relief" under the INA. ${ }^{115}$

To date, no court has found that the current reinstatement statute or regulations violate due process requirements. ${ }^{116}$ In fact, most courts that have directly addressed the issue determined that the current reinstatement of removal procedures under 8 C.F.R. $\S 241.8$ withstand constitutional scrutiny. ${ }^{117}$ The Ninth Circuit reasoned that because reentrants must have one full and fair hearing prior to being initially removed, a reinstatement order satisfies due process as long as the underlying deportation or removal proceeding itself satisfied due process. ${ }^{118}$

However, none of these courts have reached this conclusion while addressing circumstances similar to those in Fernandez-Vargas. In fact, courts that have found the provision to be valid have all examined its constitutionality as applied to reentrants who were present in the country for relatively short periods of time prior to being detected by immigration authorities. None of those illegal reentrants had established families or other significant ties to the United States. In those situations, the initial removal proceeding - consisting of a full hearing before an impartial adjudicator, including the opportunity to present evidence and develop an administrative record-was sufficient to satisfy due process demands; the initial removal hearing was held only a few years prior to reinstatement and the reentrant's circumstances had not materially changed since the initial hearing. However, where a reentrant's circumstances have materially changed and the initial hearing has become stale, due process requirements demand that a reentrant facing reinstatement receive a second hearing.

Although no courts have held that INA § 241(a)(5) violates the Due Process Clause, several courts have expressed doubts about the constitutionality of current reinstatement procedures. ${ }^{119}$ In Castro-Cortez v. INS, the Ninth Circuit Court of Appeals noted that " $\mathrm{t}] \mathrm{h}$ he reinstatement

\footnotetext{
114. Immigration and Nationality Act $§ 241(a)(5), 8$ U.S.C. $\S 1231(a)(5)(2000)$.

115. Id.

116. ReALMUTO, supra note 112, at 16.

117. E.g., Ochoa-Carrillo v. Gonzales, 437 F.3d 842, 846-48 (8th Cir. 2006); Arreola-Arreola v. Ashcroft, 383 F.3d 956, 962-63 (9th Cir. 2004); Warner v. Ashcroft, 381 F.3d 534, 538-39 (6th Cir. 2004); Alvarenga-Villalobos v. Ashcroft, 271 F.3d 1169, 1173-74 (9th Cir. 2001).

118. Arreola-Arreola, 383 F.3d at 963.

119. Lattab v. Ashcroft, 384 F.3d 8, 21 n.6 (1st Cir. 2004); Alvarez-Portillo v. Ashcroft, 280 F.3d 858, 867 (8th Cir. 2002); Bejjani v. INS, 271 F.3d 670, 675-76 (6th Cir. 2001); Castro-Cortez v. INS, 239 F.3d 1037, 1047-50 (9th Cir. 2001).
} 
process raises very serious due process concerns."120 The court stated that under the revised reinstatement provision, basic procedural safeguards had been eliminated and replaced with a summary process in which an Immigration Officer makes relevant determinations. ${ }^{121}$ The court expressed "serious doubt whether the use of Immigration Officers to determine whether to reinstate removal orders comports with due process." 122 Finally, the court noted that aliens subject to reinstatement were denied fundamental due process rights, including the opportunity to appear before an impartial decisionmaker, the right to obtain counsel, and the right to receive a full and fair hearing. ${ }^{123}$ The Ninth Circuit, while expressing serious doubts as to the reinstatement procedures' constitutionality, did not decide the issue and instead ruled in favor of the petitioning party on a narrower ground. ${ }^{124}$ Additionally, at oral argument for Fernandez-Vargas v. Gonzales, ${ }^{125}$ Justice Scalia briefly addressed the possibility of due process concerns, stating "whether it's fair or not is something we can inquire into under the due process clause." "126 However, counsel for Fernandez-Vargas chose not to raise these issues, and instead focused his efforts on arguing that the reinstatement provision had an impermissible retroactive effect when applied to his client. ${ }^{127}$

An analysis of whether the reinstatement provisions were constitutionally valid as applied to Fernandez-Vargas would have used the balancing test articulated by the Supreme Court in Mathews $v$. Eldridge. ${ }^{128}$ This test weighs the following factors: (1) "the private interest that will be affected by the official action"; (2) "the risk of an erroneous deprivation of such interest through the procedures used, and the probable value, if any, of additional or substitute procedural safeguards"; and (3) the government's interest, including "fiscal and administrative burdens that the additional or substitute procedure[s] . . would entail." 129

Under the first prong of the Mathews test, the private interests at stake were considerable. During his twenty-year presence inside the

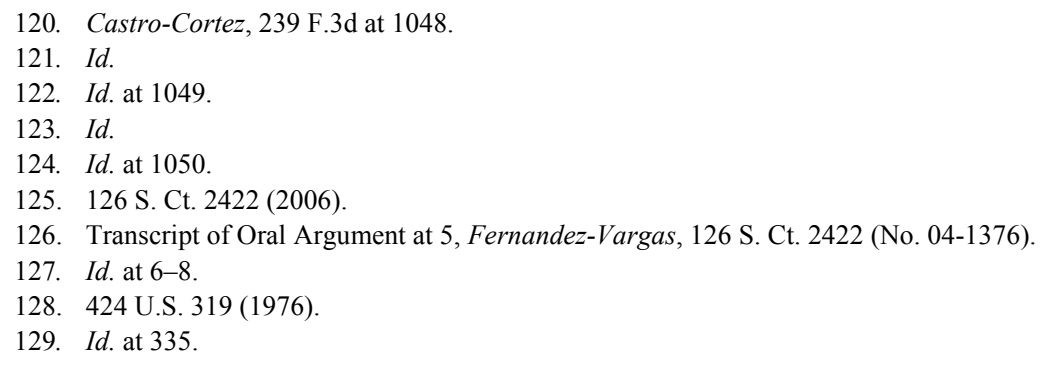


United States, Fernandez-Vargas acquired significant protectable property interests, including various items of personal property, equipment used in his business, and a personal residence. FernandezVargas also married a U.S. citizen and fathered a son.

Moving to the second prong of the Mathews test, the reinstatement procedures under INA $\S 241(\mathrm{a})(5)$ and 8 C.F.R. $\S 241.8$ allow use of a summary removal process and deny the opportunity for a second hearing. While this process may not pose a great risk of erroneous deprivation when applied to some illegal reentrants - namely, noncitizens who have not developed new property or liberty interests following their illegal reentry into the country-the risk is substantially higher where a reentrant remains in the United States long enough to establish new ties to community and family. In such situations, it is paramount that the noncitizen facing a deprivation of new property or liberty interests be allowed a second hearing before a prior removal order is reinstated. As applied to Fernandez-Vargas, the summary reinstatement procedures deprived him of his personal property, real property, and family without any of the procedural protections traditionally required by the Due Process Clause.

The final prong of the Mathews test examines the government's interest in currently used procedures. The government's main interest in maintaining the current reinstatement process is related to efficiency. Over the past generation, annual levels of immigration have tripled. ${ }^{130}$ Current estimates of the number of undocumented immigrants inside the United States range from seven million to thirteen million people. ${ }^{131}$ In 2005 alone, removal hearings resulted in the removal of 208,521 persons, of whom 18,203 were removed under INA $\S 241(a)(5)$ 's reinstatement provision. ${ }^{132}$ Based on these figures, the government has a significant interest in streamlining the removal process. Removal hearings consume time, cost money, and increase administrative burdens. The government has a legitimate interest in minimizing the consumption of these

130. Michael Fix, Wendy Zimmerman \& Jeffrey S. Passel, The Urban Inst., The INTEGRATION OF IMMIGRANT FAMILIES IN THE UNITED STATES 8 (2001), available at http://www.urban.org/publications/410227.html.

131. Office of Policy and Planning, U.S. Immigration and Naturalization Service, ESTIMATES OF THE UNAUTHORIZED IMMIGRANT POPULATION RESIDING IN THE UNITED STATES: 1990 TO 2000 1, available at http://www.dhs.gov/xlibrary/assets/statistics/publications/ Ill_Report_1211.pdf; Federation for American Immigration Reform, How Many Illegal Aliens?, http://www.fairus.org/site/PageServer?pagename=iic_immigrationissuecentersb8ca (last visited Mar. $31,2007)$.

132. Office of Immigration Statistics, U.S. Dep't of Homeland Security, 2005 YEARBOOK OF IMMIGRATION STATISTICS 96 tbl.40 (2006), available at http://www.dhs.gov/ xlibrary/assets/statistics/yearbook/2005/OIS_2005_Yearbook.pdf. 
resources, and where an illegal reentrant has already benefited from a full hearing, it does not shock the conscience, in most cases, to avoid duplicative expenditures where adequate due process has already been provided.

However, in a minority of cases, additional procedural protections are required by the Constitution. Courts have recognized that "[D]ue Process is flexible and calls for such procedural protections as the particular situation demands." 133 Courts have also held that the nature of protection owed to a reentrant can vary, depending on circumstances and the facts of his case. ${ }^{134}$ Given the extraordinary facts surrounding Fernandez-Vargas's reentry and residence in the United States, the requirements of the Due Process Clause demand that he-and other similarly situated reentrants - be provided with a second full hearing before being deprived of protectable liberty or property interests. Therefore, because the provisions of INA $\S 241(\mathrm{a})(5)$ and 8 C.F.R. $\S$ 241.8 fail to provide Fernandez-Vargas with sufficient constitutional protection, these provisions should be declared unconstitutional, or at a minimum, be limited in their application to short-term reentrants.

The fiscal and administrative burdens that a second hearing would require in cases similar to Fernandez-Vargas are minimal. The government already provides noncitizens facing an initial removal with a full hearing before an immigration judge. Illegal reentrants facing reinstatement could appear before the same judges and in the same tribunals. No new mechanisms would be required to accommodate this additional procedure. Second hearings should only be provided to illegal reentrants whose circumstances have materially changed to the extent that their first hearing is no longer sufficient to ensure adequate procedural due process protections. The number of long-term reentrants, such as Fernandez-Vargas, who would qualify for a second hearing would constitute only a fraction of the illegal reentrants removed under the reinstatement provision on an annual basis.

Immigration officers would screen illegal reentrants on a case-bycase basis to see if they possibly qualified for a second hearing. When an illegal reentrant is taken into custody, the burden of proof would be on the noncitizen to provide prima facie evidence of his or her material change in circumstance. Prima facie evidence would include, but not be limited to, evidence of when the noncitizen reentered the country, a

133. Khan v. Ashcroft, 374 F.3d 825, 830 (9th Cir. 2004) (quoting Morrisey v. Brewer, 408 U.S. 471, 481 (1972)) (alteration in original).

134. Zadvydas v. Davis, 533 U.S. 678, 693-94 (2001). 
legitimate marriage to a U.S. citizen, giving birth to or fathering a U.S.citizen child, and accumulated assets, such as personal or real property. If the noncitizen has resided in the country for an extended period, established a family, or accumulated property, then the reentrant should be able to document these facts. Reentrants who are unable to establish a prima facie case would be governed by current removal provisions and would not be afforded a second hearing. Reentrants who are identified as potentially qualifying for a second hearing would be forwarded to an immigration judge for a final determination. If the immigration judge determines that the noncitizen has established protectable interests since last being removed, then the noncitizen would be provided with a second hearing on the merits, and would be allowed to seek discretionary relief from removal under the INA. Where the immigration judge makes an adverse determination, the affected reentrant should be allowed to appeal the decision to the Board of Immigration Appeals and the federal court system, if necessary.

Likewise, this additional procedure would not seriously offend any public policy. The procedure would only benefit a select group of reentrants. Despite their illegal entries into the country and continuing unlawful presence, if reentrants have made significant ties to their communities and wish to remain in the United States, they should be given the opportunity to do so by lawful means.

B. Finding that Current Reinstatement Provisions Violate the Due Process Clause Would Promote Family Unity by Keeping MixedStatus Families of Long-Term Illegal Reentrants Together

1. Recent Immigration Laws Have Negatively Impacted Mixed-Status Families

United States immigration laws have long promoted family unity as a central value. ${ }^{135}$ "The legislative history of the Immigration and Nationality Act clearly indicates that the Congress intended to provide for a liberal treatment of children and was concerned with the problem of keeping families of United States citizens and immigrants united."136 In fact, during 2005, of 738,302 total immigrants admitted to the country as

135. See Legomsky, supra note 4, at 250 (noting that "one central value that United States immigration laws have long promoted, albeit to varying degrees, is family unity").

136. H.R. Rep. No. 85-1199, at 7 (1957), as reprinted in 1957 U.S.C.C.A.N. 2016, 2020. 
lawful permanent residents, 337,310 were admitted based on family relationships to other U.S. citizens and lawful permanent residents. ${ }^{137}$

However, despite this noble purpose, recent immigration laws, including INA $\S 241(a)(5)$, have undermined these family values. ${ }^{138}$ When noncitizens are removed, lives are uprooted. Removed noncitizens often lose everything, including their families, friends, community, jobs, and religious freedom. ${ }^{139}$ Removal also affects those left behind, often U.S. citizens, by banishing their loved ones, tearing families apart, and eliminating economic support the deported individual provided. For example, in late 2005, Fernandez-Vargas's wife, Rita, almost lost the house she and her husband had purchased together. ${ }^{140}$ "Months behind in her mortgage," Rita was forced to sell many home furnishings, while the couple's son sold his Nintendo, television, computer, and Game Boy at yard sales - all in an effort to keep their home - before three donors graciously paid off the mortgage. ${ }^{141}$

In the alternative, spouses and children may be forced to leave the United States when an individual is summarily removed from the country. ${ }^{142}$ In March 2006, Rita Fernandez described the effect her husband's removal has had on their family, saying "What about me? What about us? What about our family? Do we leave the United States and live in Mexico, a country we don't know?" "143 Such dilemmas are common in the context of removal proceedings, sparking one commentator to note that "in practice, U.S. citizen children born of alien parents in the United States are easily deportable." 144

137. See OfFice OF ImMigRation Statistics, supra note 132, at 18 tbl.6 (noting that 266,851 were immediate relatives of U.S. citizens and 70,459 were family-sponsored preferences).

138. See Nancy Morawetz, Understanding the Impact of the 1996 Deportation Laws and the Limited Scope of Proposed Reforms, 113 HARV. L. REV. 1936, 1951 (2000) (discussing some of the consequences of the INA).

139. See Linda Kelly, Preserving the Fundamental Right to Family Unity: Championing Notions of Social Contract and Community Ties in the Battle of Plenary Power Versus Aliens' Rights, 41 VILL. L. REV. 725, 763 (1996) (arguing that community ties aliens make while residing in another country should be used as a basis for determining when deportation exceptions should be made).

140. See Dennis Romboy, Yes! Home for Christmas: 3 Donors Pay Off Mortgage for Wife of Deported Man, Deseret Morning News (Salt Lake City, Utah), Dec. 22, 2005, at A01 ("Three anonymous donors stepped in to pay off the mortgage ....”).

141. Romboy, supra note 2 .

142. See David B. Thronson, Of Borders and Best Interests: Examining the Experiences of Undocumented Immigrants in U.S. Family Courts, 11 TEX. HISP. J.L. \& POL'Y 45, 67 (2005) (noting that "children of deported parents commonly leave the country with their parents").

143. Dennis Romboy, Justices Weighing Deportation Case, DESERET Morning News (Salt Lake City, Utah), Mar. 23, 2006, at A01.

144. Jorge A. Vargas, U.S. Border Patrol Abuses, Undocumented Mexican Workers, and International Human Rights, 2 SAN DIEGO INT’L L.J. 1, 15 n.43 (2001). 
2. As Applied to Certain Long-Term Reentrants, a Finding that INA $\S$ 241(a)(5) Violates the Due Process Clause is Good Public Policy

As the United States increasingly becomes home to a long-term, undocumented population, it is not surprising that members of this population marry and have children. The creation and persistence of these mixed-status families is heavily impacted by high immigration levels and harsh immigration laws. ${ }^{145}$ Undocumented noncitizens with no means of achieving legal immigration status often form families with persons who already have legal immigration status or citizenship. ${ }^{146}$ Further complicating this issue, children born in the United States are U.S. citizens at birth, regardless of the status of their parents. ${ }^{147}$ "The formation of family ties between undocumented immigrants and persons with legal immigration status in turn influences the decisions of undocumented immigrants to remain in this country."," "[Of] families with children and headed by a noncitizen, eighty-five percent are mixedstatus families."149

Keeping this statistic in mind, the Fernandez-Vargas holding makes bad public policy for two key reasons. First, of the undocumented immigrant population, it is likely that thousands of families face circumstances similar to those faced by Fernandez-Vargas. The Court's holding applies $\S 241(\mathrm{a})(5)$ to persons whose most recent removal and illegal reentry occurred before the IIRIRA's effective date, over ten years ago. Such noncitizens have likely established binding ties to the country, including ties to family, community, and property. Second, because the new reinstatement provision eliminates any possible relief from removal, it has the practical effect of encouraging noncompliance with the law; illegal immigrants will remain hidden inside the United States because they do not want to alert the government to their illegal presence by risking a border crossing or by submitting paperwork to legalize their status. The Court's ruling tells illegal reentrants there is no way for them to achieve legal status inside the country, sending them into hiding and increasing the number of undocumented immigrants living inside the United States.

\footnotetext{
145. See Thronson, supra note 142, at 52 ("[T] oday's undocumented population is notable for both its lack of prospects for legalization under current law and its relative stability."). 
In the end, persons who could have been incorporated into our nation's economy as productive "legal" members of society will remain foreigners in a land they call home. Likewise, unlawful immigrants affected by the Fernandez-Vargas ruling often have families in the United States, many of which are mixed-status families. When a noncitizen parent's deportation order is reinstated, these families will be forced to deal with the loss of a loved one. These families must then suffer either separation or relocation to a foreign and unfamiliar country. Either resolution seems a harsh result and is contrary to the value of promoting family unity. However, this result could be avoided if courts determined that INA $\S 241(\mathrm{a})(5)$, as applied to noncitizens who have established new property and liberty interests in the United States since illegally reentering, violates the Due Process Clause, and that a second hearing is required in lieu of summarily depriving these reentrants of protectable interests.

\section{CONCLUSION}

The prior version of the reinstatement statute afforded illegal reentrants facing removal several forms of relief no longer available in $\S$ 241(a)(5). When Congress passed the IIRIRA in 1996, it replaced the former section with a much harsher provision. Under $\S 241(\mathrm{a})(5)$, Congress expanded the category of illegal reentrants subject to reinstatement, removed entitlement to a second full hearing before an immigration judge, and eliminated all discretionary relief once available from the Attorney General.

On June 22, 2006, the Supreme Court ruled in Fernandez-Vargas $v$. Gonzales that the new reinstatement provision applied to an illegal reentrant whose former deportation order was issued in 1981 and who last illegally reentered the United States in 1982. Despite the fact that Fernandez-Vargas had spent the past twenty years inside the country, residing primarily in Utah, the Court held that his continued illegal presence in the country triggered the application of the current and lessforgiving reinstatement provision. As a result, his summary removal from the country was affirmed, and he is barred from reentering the United States to join his wife and child for at least ten years.

Although Fernandez-Vargas has foreclosed challenges of impermissible retroactive effect, there still remains a viable challenge to the constitutionality of INA $\S 241(\mathrm{a})(5)$ and its implementing regulation, 8 C.F.R $\S 241.8$, based on the Due Process Clause of the Fifth Amendment. Under the Due Process Clause, all persons are entitled to due process of law before being deprived of life, liberty, or property. As 
applied in Fernandez-Vargas, the new reinstatement provisions violate this constitutional mandate. Because Fernandez-Vargas's circumstances had materially changed since his 1981 deportation order-he had acquired personal property, real property, married a U.S. citizen, and fathered a son, also a U.S. citizen-due process required that the government provide him with a second full and fair hearing before removing him from the country and depriving him of these protectable property and liberty interests. Providing similarly situated reentrants with a second hearing would consume a minimum of additional resources because the mechanics to administer the hearings are already in place. Likewise, allowing a second hearing in these limited circumstances helps keep certain mixed-status families together. Not only is this result good public policy, but it also promotes a central value of U.S. immigration law-family unity. 